\title{
Carbon Dioxide Emission from European Estuaries
}

\author{
Michel Frankignoulle,* Gwenaël Abril, Alberto Borges, \\ Isabelle Bourge, Christine Canon, Bruno Delille, Emile Libert, \\ Jean-Marie Théate
}

\begin{abstract}
The partial pressure of carbon dioxide $\left(\mathrm{pCO}_{2}\right)$ in surface waters and related atmospheric exchanges were measured in nine European estuaries. Averaged fluxes over the entire estuaries are usually in the range of 0.1 to 0.5 mole of $\mathrm{CO}_{2}$ per square meter per day. For wide estuaries, net daily fluxes to the atmosphere amount to several hundred tons of carbon (up to 790 tons of carbon per day in the Scheldt estuary). European estuaries emit between 30 and 60 million tons of carbon per year to the atmosphere, representing 5 to $10 \%$ of present anthropogenic $\mathrm{CO}_{2}$ emissions for Western Europe.
\end{abstract}

Although very few data are available so far, estuaries are known to show significant supersaturation of $\mathrm{CO}_{2}$ with respect to the atmosphere (1-3). Partial $\mathrm{CO}_{2}$ pressures $\left(\mathrm{pCO}_{2}\right)$ as high as $5700 \mu$ atm have recently been reported (2) at the turbidity maximum in the Scheldt estuary (Belgium and Netherlands), which is about 16 times the $\mathrm{pCO}_{2}$ of the present atmospheric equilibrium (360 $\mu \mathrm{atm})$. Such high $\mathrm{pCO}_{2}$ values result from intricate biological and physicochemical processes that characterize estuarine dynamics. Estuaries are obligate pathways for the transfer of dissolved and particulate material from the continent to the marine system. The tidal regime of some estuaries leads to an increased residence time of the fresh water in the estuarine mixing zone, and pronounced changes in the speciation of elements may occur.

European estuaries are subject to intense anthropogenic disturbance (4) reflected in elevated loadings of detrital organic matter which induces high respiration rates (5) and the production of large quantities of dissolved $\mathrm{CO}_{2}$ (2). Estuaries are considered to be net heterotrophic ecosystems $(6,7)$, but the order of magnitude of the resulting atmospheric $\mathrm{CO}_{2}$ source is still a matter of debate $(8-11)$.

The total surface area of estuaries in Europe has been estimated (3) to be 111,200 $\mathrm{km}^{2}$, calculated from marine areas where salinity is lower than 34 and excluding the Baltic Sea. This surface area includes both estuarine embayments (inner estuaries) and river plumes at sea (outer estuaries). The relative importance of these systems, in terms of respective areas, depends on hydrological conditions, such as the freshwater flow, the tidal regime, and the topography of the estu-

Université de Liège, Mécanique des Fluides Géophysiques, Unité d'Océanographie Chimique, Institut de Physique (B5), B4000 Liège, Belgium.

*To whom correspondence should be addressed. Email: Michel.Frankignoulle@ulg.ac.be ary. In macrotidal estuaries, most of the mixing between fresh water and seawater occurs within the inner estuary; that of the outer estuary is relatively small.

We have simultaneously measured the surface $\mathrm{pCO}_{2}$ and related atmospheric fluxes during 25 cruises in nine European inner estuaries (Table 1) and during 13 cruises in outer estuaries (Table 2). These data were collected in estuaries displaying a range of different hydrological conditions, from low freshwater flow and long residence time of water within the inner estuary (such as the Scheldt estuary) to high freshwater flow and short residence time (for example, the Rhine estuary).

Figure 1 shows an example of $\mathrm{pCO}_{2}$ and related flux values measured in the Scheldt estuary in July 1996. Both the $\mathrm{pCO}_{2}$ and the efflux increase when salinity decreases. $\mathrm{pCO}_{2}$ and dissolved oxygen profiles obtained in the Scheldt, the Thames, the Gironde, and the Rhine estuaries (Fig. 2) illustrate that the $\mathrm{pCO}_{2}$ variation with salinity is quite different from one estuary to another, though the supersaturation is always high. All four estuaries show a clear increase of $\mathrm{pCO}_{2}$ within the upper estuary (low salinity), which is associated with a decrease in oxygen saturation. This increase in $\mathrm{pCO}_{2}$ is located at the turbidity maximum, at a salinity of about 1 in both the Gironde and the Rhine estuary, and a salinity of 10 in the Thames estuary. The Scheldt is already heavily polluted in the freshwater members and, in November 1997, we carried out sampling in the upper estuary, in the tidal river, and in the tributaries (Fig.

Table 1. Data collected during research cruises within inner estuaries. Before $1995, \mathrm{pCO}_{2}$ was calculated from total alkalinity and $\mathrm{pH}$ measurements, the latter being calibrated using buffers proposed by the U.S. National Bureau of Standards. After 1995, a system coupling an equilibrator and an infrared gas analyzer (Li-Cor 6262, Li-Cor, Lincoln, Nebraska), was used for $\mathrm{pCO}_{2}$ lower than $3500 \mu$ atm. Lower $\mathrm{pCO}_{2}$ values are from the river mouth (lower estuary, high salinity), whereas higher values are from the turbidity maxima (see also Fig. 1), usually located in the upper estuary (low salinity). Fluxes were measured in the field (28) or calculated (*) according to (27). The net daily flux is calculated over the entire surface of estuaries, and the mean flux is the corresponding averaged value per square meter.

\begin{tabular}{|c|c|c|c|c|}
\hline Country & Cruises (inner estuaries) & $\begin{array}{l}\mathrm{PCO}_{2} \\
\text { range } \\
\text { ( } \mu \text { atm) }\end{array}$ & $\begin{array}{l}\text { Mean flux } \\
\left(\text { mol m}^{-2}\right. \\
\left.\text { day }^{-1}\right)\end{array}$ & $\begin{array}{l}\text { Net daily flux } \\
\left(\text { tC day }^{-1}\right)\end{array}$ \\
\hline Germany & Elbe, April 1997 & $580-1100$ & 0.18 & 570 \\
\hline $\begin{array}{l}\text { Germany/ } \\
\text { Netherlands }\end{array}$ & Ems, July 1997 & $560-3755$ & 0.19 & 310 \\
\hline \multirow[t]{3}{*}{ Netherlands } & Rhine, October 1996 & $585-1875$ & 0.08 & 65 \\
\hline & Rhine, July 1997 & $545-1990$ & 0.16 & 134 \\
\hline & Rhine, November 1997 & $560-1425$ & 0.07 & 56 \\
\hline \multirow{10}{*}{$\begin{array}{l}\text { Netherlands/ } \\
\text { Belgium }\end{array}$} & Scheldt, March 1993 & $480-5700$ & 0.50 & 600 \\
\hline & Scheldt, June 1993 & $125-7200$ & 0.38 & 460 \\
\hline & Scheldt, March 1994 & $400-4450$ & 0.35 & 420 \\
\hline & Scheldt, November 1994 & $715-9425$ & 0.66 & 790 \\
\hline & Scheldt, January 1995 & $530-8610$ & 0.4 & 480 \\
\hline & Scheldt, August 1995 & $350-7400$ & 0.26 & 310 \\
\hline & Scheldt, November 1995 & $600-5800$ & 0.33 & 390 \\
\hline & Scheldt, July 1996 & $560-7100$ & 0.46 & 550 \\
\hline & Scheldt, September 1996 & $620-6220$ & $0.35^{*}$ & $420 *$ \\
\hline & Scheldt, December 1996 & $580-5630$ & 0.29 & 340 \\
\hline \multirow[t]{4}{*}{ United Kingdom } & Tamar, March 1992 & $380-1450$ & $0.09 *$ & $12^{*}$ \\
\hline & Tamar, July 1992 & $400-2200$ & $0.12 *$ & $15^{*}$ \\
\hline & Thames, November 1994 & $505-5200$ & $0.29 *$ & $720 *$ \\
\hline & Thames, September 1996 & $465-4600$ & 0.21 & 520 \\
\hline \multirow[t]{5}{*}{ France } & Gironde, April 1994 & $465-1230$ & $0.11 *$ & $550 *$ \\
\hline & Gironde, October 1996 & $480-1200$ & 0.09 & 470 \\
\hline & Gironde, June 1997 & $580-2860$ & 0.11 & 590 \\
\hline & Gironde, September 1997 & $530-2540$ & 0.07 & 380 \\
\hline & Gironde, February 1998 & $440-980$ & 0.05 & 250 \\
\hline \multirow[t]{2}{*}{ Portugal } & Douro, September 1997 & $1330-2200$ & 0.24 & 6 \\
\hline & Sado, September 1997 & $575-5700$ & 0.76 & 105 \\
\hline
\end{tabular}




\section{R E P O R T S}

3). The $\mathrm{pCO}_{2}$ is quite high in the tributaries but increases drastically at the entrance of the estuary, together with a drop in particulate organic carbon (POC). The $\mathrm{CO}_{2}$ distribution within estuaries is therefore the result of physical mixing of supersaturated freshwater with seawater, of marked heterotrophy in the upper estuary, and of $\mathrm{CO}_{2}$ efflux to the atmosphere. Annual budget calculations have shown that $50 \%$ and $>90 \%$ of the POC load transported into the Gironde (12) and the Scheldt (5), respectively, are mineralized in the turbidity maximum. In contrast, dissolved

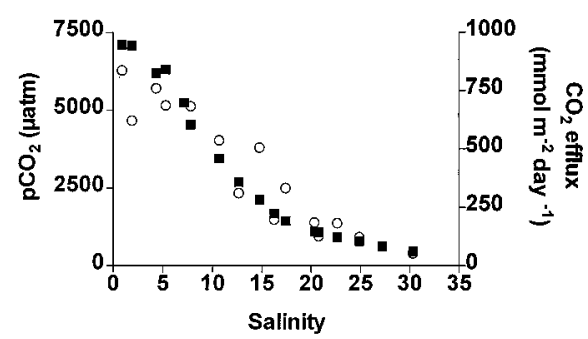

Fig. 1. Surface $\mathrm{pCO}_{2}$ (in microatmospheres; full squares) and $\mathrm{CO}_{2}$ efflux (in millimoles per square meter per day; open circles) measured in the inner Scheldt estuary in July 1996 as a function of salinity. See legend of Table 1 for technical details. organic carbon (DOC) is mostly refractory and behaves conservatively through estuaries (13). Table 1 shows that the highest $\mathrm{pCO}_{2}$ values at the turbidity maximum range from $1100 \mu \mathrm{atm}$ in the Elbe estuary in April 1997 to $9500 \mu \mathrm{atm}$ in the Scheldt estuary in November 1994. For inner estuaries, where the total surface is known, corresponding net daily fluxes to the atmosphere have been calculated from discrete $\mathrm{CO}_{2}$ flux measurements. Except for the small estuaries, $\mathrm{CO}_{2}$ fluxes amount to several hundred tons of $\mathrm{C}(\mathrm{tC})$, with a maximum of $790 \mathrm{tC}^{\mathrm{day}}{ }^{-1}$ in November 1994 in the Scheldt estuary.

The POC mineralization produces 150 and $400 \mathrm{tC}$ daily in the Gironde and the Scheldt estuaries, respectively. The flux values given in Table 1 then suggest that, in the Scheldt, about two-thirds of the flux results from heterotrophy, with the remaining third resulting from physical ventilation. In the Gironde estuary, about one-third of the atmospheric flux is due to heterotrophy.

In polluted European estuaries, most of the labile carbon that is respired is anthropogenic $(4,5)$. Other pollution-related processes, such as nitrification in the Scheldt estuary $(2,14)$, may also acidify estuarine water and favor the $\mathrm{CO}_{2}$ flux to the atmosphere.


Fig. 2. Distribution of $\mathrm{pCO}_{2}$ (in microatmospheres; full squares, left axis) and dissolved oxygen (as percent saturation; open circles, right axis) as a function of salinity in the surface waters of some investigated inner estuaries.

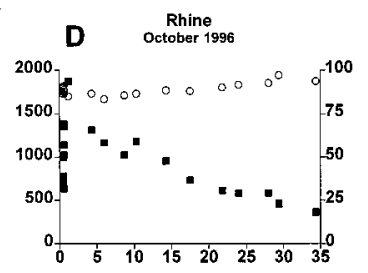

Table 2. Data collected during research cruises in outer estuaries. Low $\mathrm{pCO}_{2}$ values correspond to high salinity values. See legend to Table 1 for technical details.

\begin{tabular}{lccc}
\hline Cruises (outer estuaries) & $\begin{array}{c}\text { Salinity } \\
\text { range }\end{array}$ & $\begin{array}{c}\mathrm{PCO}_{2} \text { range } \\
(\mu \mathrm{atm})\end{array}$ & $\begin{array}{c}\text { Mean flux } \\
\left(\mathrm{mol} \mathrm{m}^{-2} \text { day }^{-1}\right)\end{array}$ \\
\hline Elbe, April 1997 & $12-30$ & $580-340$ & 0.02 \\
Ems, July 1997 & $30-34$ & $560-525$ & 0.03 \\
Rhine, October 1996 & $25-34$ & $585-385$ & 0.02 \\
Rhine, July 1997 & $18-33$ & $545-375$ & 0.015 \\
Rhine, November 1997 & $25-31$ & $560-430$ & 0.015 \\
Scheldt, July 1996 & $30-32$ & $560-540$ & 0.035 \\
Scheldt, September 1996 & $30-34$ & $620-450$ & $0.03^{*}$ \\
Scheldt, December 1996 & $30-34$ & $580-450$ & 0.03 \\
Scheldt, March 1997 & $30-34$ & $580-240$ & 0 \\
Scheldt, August 1997 & $31-34$ & $640-410$ & $0.03^{*}$ \\
Gironde, September 1997 & $30-33$ & $580-550$ & 0.035 \\
Douro, September 1997 & $9-30$ & $1330-385$ & 0.05 \\
Sado, September 1997 & $32-34$ & $575-450$ & 0.03 \\
\hline
\end{tabular}

These data show that the investigated inner estuaries are a $\mathrm{CO}_{2}$ source to the atmosphere, ranging from about $0.10 \mathrm{~mol} \mathrm{~m}^{-2}$ day $^{-1}$ to $0.76 \mathrm{~mol} \mathrm{~m}^{-2}$ day $^{-1}$. The estuarine area we studied emits 3000 tC daily to the atmosphere, corresponding to a mean flux of $0.17 \mathrm{~mol} \mathrm{~m}^{-2}$ day $^{-1}$.

Outer estuaries can differ substantially from inner estuaries as sources for atmospheric $\mathrm{CO}_{2}$. The outer estuary can be a site of intense primary production, because of eutrophication, and can behave as a sink for atmospheric $\mathrm{CO}_{2}$. The data in Table 1 show that significant undersaturation occurred in the lower Scheldt in June 1993, but that supersaturation was observed in all other cases. A time series of measurements, carried out over 18 months in the outer Scheldt estuary, shows that undersaturation only occurs for a few weeks during the spring phytoplanktonic bloom (15). Table 2 shows that supersaturation appears to be the general tendency in the outer estuary, and rates of efflux are about one order of magnitude lower than in the inner estuary (Table 1).

The above considerations have been used to

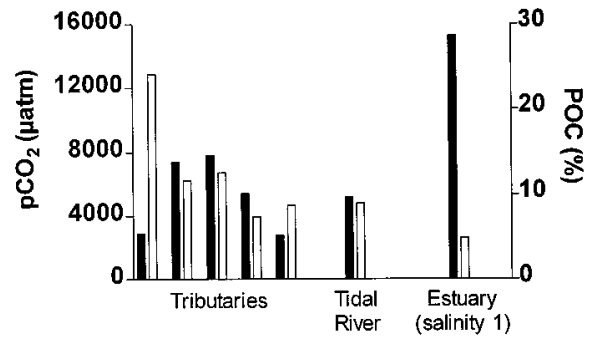

Fig. 3. $\mathrm{PCO}_{2}$ (solid bars, left axis) and particulate organic carbon (as percent suspended particulate material; open bars, right axis) in the upper Scheldt estuary (city of Antwerp), in the tidal river (35 km from Antwerp), and in some tributaries (60 km from Antwerp) in November 1997.

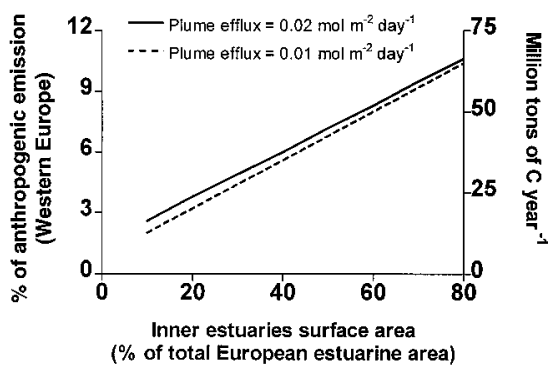

Fig. 4. Total carbon emission from European estuaries computed by taking into account the variability of the surface area for inner estuaries and the efflux from outer estuaries. Based on our data, the efflux from inner estuaries was taken as $0.15 \mathrm{~mol} \mathrm{~m}^{-2}$ day $^{-1}$. Assuming that $20 \%$ of the European estuarine surface area are inner estuaries, with an efflux of $0.15 \mathrm{~mol} \mathrm{~m}^{-2}$ day $^{-1}$, the outer estuarine influx should amount to $-0.04 \mathrm{~mol} \mathrm{~m}^{-2}$ day $^{-1}$ to yield a global null flux. 


\title{
R E P O R T S
}

estimate total $\mathrm{CO}_{2}$ emission from European estuaries (Fig. 4), which appears to be a significant percentage of the present anthropogenic $\mathrm{CO}_{2}$ release to the atmosphere from Western Europe due to combustion [647 million tons of $\mathrm{C}$ in 1995 (16)]. A minimum estimate, calculated by applying an outer estuarine efflux of $0.01 \mathrm{~mol} \mathrm{~m}^{-2}$ day $^{-1}$ to $80 \%$ of the total European estuarine surface area, yields a total European emission of 20 million tons of C per day, representing $3 \%$ of the present anthropogenic emission of $\mathrm{CO}_{2}$ from Western Europe. It is likely that the percentage of surface area of inner estuaries is in the range of 25 to $50 \%$ and, from data presented here, we estimate the actual value to be in the range of 30 to 60 million tons of $\mathrm{C}$ per day, which is 5 to $10 \%$ of the present European anthropogenic emission. This percentage has been obtained for a highly industrialized area of the world; it may be higher for developing countries, where anthropogenic $\mathrm{CO}_{2}$ emissions are lower and where significant organic carbon load results from overpopulation.

Few data are available for other estuaries in the world, but the available data shows a high degree of supersaturation $(1,17-19)$, ranging from 500 to $6000 \mu \mathrm{atm}$. Some data are also available for major rivers. The carbon budget of the Amazon has been studied (20), and it was shown that this river emits 0.17 to $0.52 \mathrm{~mol} \mathrm{~m}^{-2}$ day $^{-1}$, very similar to our flux data. Carbon dioxide levels have been measured in the Niger (21), and the highest values reported were $\sim 6400 \mu \mathrm{atm}$, again in agreement with values reported here.

References and Notes

1. S. Kempe, Mitt. Geol.-Palaeontol. Inst. Univ. Hamburg 52, 719 (1982).

2. M. Frankignoulle, I. Bourge, R. Wollast, Limnol. Oceanogr. 41, 365 (1996).

3. P. M. Woodwell, P. H. Rich, C. A. S. Hall, in Carbon and the Biosphere, P. M. Woodwell and E. V. Pecan, Eds. (U.S. National Technical Information Service, Springfield, VA, 1973), pp. 221-240.

4. S. Kempe, J. Geophys. Res. 89, 4657 (1984).

5. R. Wollast, in Pollution of the North Sea, An Assessment, W. Salonmons, B. L. Baynes, E. K. Duursma, U. Förstner, Eds. (Springer-Verlag, Berlin, 1988), Pp. 185-193.

6. S. V. Smith and J. T. Hollibaugh, Rev. Geophys. 31, 75 (1993).

7. J.-P. Gattuso, M. Frankignoulle, R. Wollast, Annu. Rev. Ecol. Syst. 29, 405 (1998).

8. C. H. R. Heip et al., Oceanogr. Mar. Biol. Annu. Rev. 33, 1 (1995).

9. W. H. Schlesinger, Ed., Biogeochemistry: An Analysis of Global Change (Academic Press, London, 1997).

10. S. Kempe, LOICZ Reports \& Studies 1, 1 (1995).

11. S. V. Smith and J. T. Hollibaugh, Ecol. Monogr. 67, 509 (1997).

12. H. Etcheber, thesis, Université de Bordeaux (1986).

13. R. F. C. Mantoura and E. M. S. Woodward, Geochim. Cosmochim. Acta 47, 1293 (1983).

14. G. Billen, Estuarine Coastal Shelf Sci. 3, 79 (1975).

15. A. V. Borges and M. Frankignoulle, J. Mar. Syst., in press.

16. G. Marland, T. A. Boden, A. Brenkert, R. J. Andres, J. G. J. Olivier, in Fifth International Carbon Dioxide Conference, Cairns, Australia, 8 to 12 September 1997 (CSIRO, Aspendale, Australia, 1997), p 4.
17. P. K. Park, L. I. Gordon, S. W. Hager, M. C. Cissel, Science 166, 867 (1969).

18. P. A. Raymond, N. F. Caraco, J. J. Cole, Estuaries 20, 381 (1996).

19. W.-J. Cai and Y. Wang, Limnol. Oceanogr. 43, 657 (1998).

20. J. E. Richey, R. L. Victoria, E. Salati, B. R. Forsberg, in Biogeochemistry of Major World Rivers, E. T. Degens, S. Kempe, E. Richey, Eds. (Wiley, New York, 1991), Pp. 57-74.

21. O. Martins and J.-L. Probst, in (20), pp. 127-155.

22. P. S. Liss and L. Merlivat, in The Role of Air-Sea Exchange in Geochemical Cycling, P. Buat-Ménard, Ed. (NATO ASI Series, Reidel, Utrecht, Netherlands, 1986), pp. $113-128$

23. F. Jordan, F. Clark, R. Wanninkhof, P. Schlosser, H. James, Tellus B 46, 274 (1994).

24. R. Wanninkhof, J. Geophys. Res. 97, 7373 (1992).

25. J. P. Bennet and R. E. Rathbun, U.S. Geol. Surv. Prof. Pap. 737 (1972).

26. M. Frankignoulle, Limnol. Oceanogr. 33, 313 (1988)

27. $F=K \alpha \Delta P$, where $F$ is the flux in $\mathrm{mol} \mathrm{m}^{-2} \mathrm{~s}^{-1}, K$ is the exchange coefficient in $\mathrm{m} \mathrm{s}^{-1}, \alpha$ is the $\mathrm{CO}_{2}$ solubility coefficient in $\mathrm{mol} \mathrm{m}^{-3} \mathrm{~atm}^{-1}$, and $\Delta P$ is the $\mathrm{CO}_{2}$ gradient through the interface $\left[\mathrm{pCO}_{2 \text { (water) }}\right.$ $\mathrm{pCO}_{2}$ ] in atmospheres. An exchange coefficient of $2 \times 10^{-5} \mathrm{~m} \mathrm{~s}^{-1}$ (that is, $\left.8 \mathrm{~cm} \mathrm{hour}^{-1}\right)(2,22,23)$ was used for a Schmidt number Sc $=600$ (24), which is a typical value for a moderately turbulent river (25).

28. Atmospheric exchanges of $\mathrm{CO}_{2}$ were measured using the direct floating chamber method (26) adapted for operation in estuarine environments (2). The chamber was set up on a lagrangian system in order to avoid creation of turbidity due to estuarine current and to follow the same water mass. Measurements were typically carried out each 2.5 salinity step through the whole estuary. Wind speed is usually low in investigated areas $\left(0\right.$ to $\left.5 \mathrm{~m} \mathrm{~s}^{-1}\right)$, and the exchange coefficient $K$ (27) is mainly determined by the turbulence of the water column. Calculated values of $K$, from measured flux and $\mathrm{CO}_{2}$ gradient (27), is in good agreement with those reported for rivers (25). It should be pointed out that, if wind becomes predominant, actual efflux would be higher than our estimate.

29. We thank the crews and technicians who were involved in the numerous cruises, R. Wollast and two anonymous referees for helpful comments on a previous version of this manuscript, and A. Pollentier, J. Backers, and A. Peliz for providing salinity and temperature data. Funded by the Fonds National de la Recherche Scientifique (FNRS, Belgium), with which the senior author is a research associate, and the European Union [Marine Science and Technology (MAST) and Environment and Climate programs]. This is a contribution to the European Land Ocean Interactions Studies (ELOISE) Programme (publication number 037) in the framework of the Biogas Transfer in Estuaries (BIOGEST) project carried out under contract ENV4-CT96-0213.

23 June 1998; accepted 28 August 1998

\section{A Short Circuit in Thermohaline Circulation: A Cause for Northern Hemisphere Glaciation?}

\author{
N. W. Driscoll and G. H. Haug
}

\begin{abstract}
The cause of Northern Hemisphere glaciation about 3 million years ago remains uncertain. Closing the Panamanian Isthmus increased thermohaline circulation and enhanced moisture supply to high latitudes, but the accompanying heat would have inhibited ice growth. One possible solution is that enhanced moisture transported to Eurasia also enhanced freshwater delivery to the Arctic via Siberian rivers. Freshwater input to the Arctic would facilitate sea ice formation, increase the albedo, and isolate the high heat capacity of the ocean from the atmosphere. It would also act as a negative feedback on the efficiency of the "conveyor belt" heat pump.
\end{abstract}

Major ice sheet growth in Eurasia, Greenland, and North America is recorded by a $\delta^{18} \mathrm{O}$ enrichment in benthic foraminifera between 3.1 and 2.5 million years ago $(\mathrm{Ma})$ $(1,2)$ and by the massive appearance of ice-rafted debris in northern high-latitude oceans since $2.7 \mathrm{Ma}(3)$. An increase in the $\delta^{18} \mathrm{O}$ value of benthic foraminifera predominantly reflects the growth of continental ice volume. The intensification of Northern Hemisphere glaciation (NHG) finalizes the

N. W. Driscoll, Woods Hole Oceanographic Institution, Woods Hole, MA 02543, USA. G. H. Haug, GEOMAR, Forschungszentrum für Marine Geowissenschaften, Universität Kiel, Wischhofstrasse 1-3, D-24148 Kiel, Germany.
Cenozoic cooling trend, which started in the early Eocene and is marked by the first indications of ice sheets in Antarctica 36 Ma (4). This long-term cooling brought the climate system of Earth to a state critical for ice sheet buildup in the Northern Hemisphere. This has been the case since approximately $11 \mathrm{Ma}$, when the first and minor occurrence of ice-rafted debris in the Arctic and North Atlantic indicates the first attempts of the climate system to start a glaciation (5). However, the climate system failed to generate and maintain major ice sheets in the Northern Hemisphere until 2.7 Ma. Here we suggest that the closure of the Isthmus of Panama, which enhanced moisture transport to the Eurasian continent, 